\title{
Perlindungan Hukum Terhadap Hak Pendidik Di Wilayah Perbatasan Indonesia Dan Malaysia
}

\author{
Endah Rantau Itasari ${ }^{*}$ \\ ${ }^{1}$ Universitas Tanjungpura, Kalimantan Barat. \\ *e-mail: endah.rantau.itasari@hukum.untan.ac.id \\ Article history: Received 04 August 2020; Accepted 30 August 2020; Available online 31 August 2020
}

\begin{abstract}
Abstrak
Penelitian ini bertujuan untuk mengetahui perlindungan hukum yang diberikan oleh negara kepada warga negaranya khususnya di wilayah perbatasan antara Indonesia dengan Malaysia berkenaan dengan hak pendidikan yang diterima oleh warga negara Indonesia. Metode penelitian yang digunakan ialah menggunakan penelitian hukum yuridis normatif. Hasil penelitian menunjukan bahwa hak-hak warga negara Indonesia khususnya tentang hak pendidikan telah diberikan dalam undang-undang Republik Indonesia, dan diatur di dalam undang-undang hak asasi manusia dimana setiap warga negara diberikan hak pendidikan dan hak pekerjaan di wilayah kedaulatan Indonesia, bahkan Bangsa Indonesia telah meratifikasi peraturan Internasional The Universal Declaration on Human Rights (UDHR) 1949, The International Covenant on Economic, Social and Cultural Rights (ICESCR)1966 dan dalam The Convention on The Rights of The Child 1989 yang seluruhnya memberikan perlindungan hukum kepada setiap warga negara di dalam memperoleh pendidikan. Jadi pemerintah pusat wajib memberikan hak pendidikan kepada seluruh warga negara yang ada di wilayah perbatasan tanpa terkecuali karena hal ini merupakan amanat konstitusi Indonesia.
\end{abstract}

\begin{abstract}
This study aims to determine the legal protection provided by the state to its citizens, especially in the border region between Indonesia and Malaysia with regard to the right to education received by Indonesian citizens. The research method used is to use normative legal research. The results of the study show that the rights of Indonesian citizens, especially regarding the right to education, have been given in the laws of the Republic of Indonesia, and regulated in a human rights law where every citizen is given the right to education and work rights in the sovereignty of Indonesia, even the Nation Indonesia has ratified the Universal Declaration on Human Rights (UDHR) 1949 International regulations, The International Covenant on Economic, Social and Cultural Rights (ICESCR) 1966 and in the 1989 Convention on The Rights of the Child which all provide legal protection to every citizen in getting an education.
\end{abstract}

\section{Kata Kunci:}

Perlindungan hukum; Hak pendidikan; Wilayah perbatasan

\section{Keywords:}

Legal protection, Education rights, Border areas 


\section{Pendahuluan}

Eksistensi hak atas pendidikan sudah tidak diragukan lagi keberadaannya baik di tingkat nasional maupun internasional (Beiter.2005). Khusus di Indonesia, dinamika politik hukum nasional mempengaruhi pelaksanaan hak atas pendidikan yang berasal dari Undang-Undang Dasar Negara Republik Indonesia Tahun 1945 (UUD 1945) dan ketentuan-ketentuan pokok hukum hak asasi manusia internasional seperti dalam The Universal Declaration on Human Rights (UDHR) 1949, The International Covenant on Economic, Social and Cultural Rights (ICESCR)1966 dan dalam The Convention on The Rights of The Child 1989.

Dalam Pembukaan UUD 1945 ditegaskan bahwa salah satu tujuan dibentuknya pemerintahan Negara Indonesia adalah "untuk mencerdaskan kehidupan bangsa". Tujuan ini kemudian dimanifestasikan melalui Pasal 28C ayat (1) dan Pasal 31 UUD 1945 dan dijabarkan lebih lanjut dalam berbagai peraturan perundang-undangan termasuk Undang-Undang No. 20 Tahun 2003 tentang Sistem Pendidikan Nasional sebagai lex specialis. Berkaitan dengan ICESCR, Indonesia telah meratifikasi kovenan tersebut pada tanggal 30 September 2005 melalui UndangUndang Nomor 11 Tahun 2005 tentang Pengesahan theInternational Covenant on Economic, Social and Cultural Rights. Dalam ICESCR sendiri hak atas pendidikan khususnya diatur dalam Pasal 13 dan Pasal 14.

Hakekat hak atas pendidikan pada tingkat pendidikan dasar, sebagaimana ditegaskan dalam ICESCR, merupakan suatu kondisi tertentu harus diciptakan oleh negara peratifikasi (Freeman;1992). Aspek substansi pendidikan dan manajerial penyelenggaraan pendidikan merupakan elemen dasar dalam Pasal 13 ICESCR bagi negara untuk menyediakan pendidikan dasar bagi setiap orang. Aspek ketersediaan dan kemudahan sarana dan prasarana pendidikan, dan aspek penerimaan dan daya penyesuaian merupakan segmen-segmen hukum (indikator) yang harus dikondisikan pemenuhannya secara bertahap oleh negara untuk setiap saat dicapai dan ditingkatkan pemenuhannya dalam bidang pendidikan, khususnya pendidikan dasar dan menengah (Eide;1995).

Indonesia sebagai pihak pada ICESCR terikat untuk melaksanakan ketentuan-ketentuan tersebut berdasarkan kewajiban-kewajian internasional yang terkandung didalamnya (Santos Pais). Bonanza Perwira Taihitu memberikan kerangka argumentatif bahwa politik hukum nasional Indonesia terhadap pelaksanaan ketentuan-ketentuan hukum hak asasi manusia internasional tersebut di atas antara tahun 1990 sampai dengan akhir tahun 2005 lebih cenderung bersifat sebagai sebuah pencitraan nasional di forum internasional (Perwira Taihitu ;2003). Dengan demikian, kewajiban-kewajiban dasar dalam ketentuan tersebut dilaksanakan untuk lebih menarik simpati luar negeri dari pada pemanfaatannya untuk kepentingan nasional.

Menjadi menarik untuk dikaji apakah sifat dan tujuan politik hukum nasional di Indonesia terhadap pemenuhan hak atas pendidikan, khususnya pendidikan dasar dan menengah setelah amandemen UUD 1945. Motivasi tersebut apakah menjiwai terhadap implementasi ICESCR menjadi suatu kajian yuridis yang kaya makna. Kajian yuridis tersebut terkait dengan 11 kluster temuan permasalahan pemenuhan hak atas pendidikan oleh Kementerian Pendidikan dan Kebudayaan Republik Indonesia (Kemdikbud RI). Salah satu kluster permasalahan tersebut adalah permasalahan pemenuhan hak anak atas pendidikan dasar dan menengah di wilayah perbatasan Indonesia dengan wilayah lainnya seperti dengan Malaysia, Papua Nugini (PNG) dan Republic Demokratik Timor Leste (RDTL).

Dalam tataran normatif, untuk memastikan pemenuhan kebutuhan masyarakat akan pendidikan yang layak, negara mempunyai kewajiban untuk memastikan penyedian sistem pendidikan dan kurikulum yang memadai, penyediaan beasiswa, penyediaan sarana dan prasarana yang memadai, meningkatkan kualitas tenaga pendidik baik guru maupun dosen di perguruan tinggi (The Right to Education;1999). Menurut kewajiban yang terkandung dalam ICESCR, sistem pendidikan yang ditetapkan oleh pemerintah harus dapat menjangkau semua warganegara, dapat diakses secara bebas tanpa diskriminasi dan secara ekonomi dan psikologis 
dapat diterima, serta sifatnya dapat menyesuaikan diri dengan perkembangan zaman (Wringe, 2006).

Dengan kebijakan pemerintahan saat ini yang ingin memulai pembangunan dari wilayah perbatasan dan wilayah terluar semestinya kondisi pemenuhan hak atas pendidikan bagi masyarakat di wilayah perbatasan menjadi salah satu prioritas. Dengan demikian diperlukan sebuah kajian untuk mendapatkan gambaran mengenai politik hukum dan kebijakan negara dalam memenuhi hak atas pendidikan dasar dan menengah bagi masyarakat di perbatasan Kalimantan Barat dengan Sarawak. Analisis situasi dan kebutuhan terhadap pemenuhan hak atas pendidikan dasar dan menengah di wilayah perbatasan negara di Provinsi Kalimantan Barat perlu dilakukan secara menyeluruh terhadap kebijakan, program, kegiatan dan pendanaan dalam pemenuhan hak atas pendidikan.

Pelaksanaan indikator-indikator tersebut akan menghasilkan akuntabilitas dan legitimasi yang dapat diterima khususnya dalam implementasi instrumen-instrumen hukum internasional yang telah diratifikasi Indonesia. Secara teoritis praktis, indikator legal pelaksanaan tersebut di atas dapat diukur melalui sistematisasi pada budaya hukum (legal culture); struktur hukum (legal structure) dan substansi hukum (legal substance) terhadap upaya pemenuhan hak atas pendidikan. Daya paksa berlakunya hukum akan memperoleh justifikasi legal, sosial dan politik sehingga pemberlakuan ini dapat digunakan sebagai referensi bagi pemenuhan hak atas pendidikan dasar dan menengah di wilayah perbatasan Indonesia khususnya di Kalimantan Barat dengan Malaysia.

\section{Metode}

Dalam Penelitian ini adalah penelitian yang bersifat deskriptif yaitu penelitian yang bermaksud untuk memberikan data yang seteliti mungkin mengenai Perlindungan Hukum Terhadap Warga Negara Untuk Memperoleh Hak Pendidikan di Wilayah Perbatasan Indonesia dan Malaysia. Penelitian ini adalah penelitian evaluatif dan preskriptif. Dikatakan penelitian evaluatif karena penelitian ini bermaksud memberikan analisis yang mendalam terhadap perlindungan hukum warga negara Indoensia untuk memperoleh hak pendidikan di wilayah perbatasan, sedangkan penelitian preskriptif karena penelitian ini juga akan memberikan solusi yang tepat berdasarkan prinsip-prinsip hukum internasional serta hukum hak asasi manusia khususnya di bidang pendidikan untuk mengatasi hambatan-hambatan di dalam melakukan pemenuhan hak asasi pendidikan di daerah dan kawasan perbatasan antara Indonesia dan Malaysia. Dari segi tujuan, penelitian hukum ini adalah penelitian hukum normatif dan kepustakaan.

Penelitian ini menggunakan pendekatan undang-undang (statute approach), dan pendekatan konseptual (conceptual approach). Pendekatan undang-undang digunakan oleh peneliti untuk mengkaji atau menelaah semua peraturan yang berkaitan dengan politik hukum nasional Indonesia atas pemenuhan hak pendidikan di wilayah perbatasan. Kajian terhadap peraturan dilakukan dari peraturan yang tinggi tingkatannya sampai pada peraturan yang paling rendah berdasarkan tata urutan perundang-undangan yang berlaku. Adapun pendekatan konseptual yang dilakukan dalam penelitian ini adalah mengkaji doktrin, asas, serta konsep dalam ilmu ilmu hukum dikaitkan dengan isu hukum yang menjadi pokok permasalahan yang peneliti kaji. Pendekatan konseptual diharapkan melahirkan argumentasi hukum yang dapat memecahkan permasalahan dan isu hukum yang peneliti kaji terutama yang berkaitan dengan politik hukum nasional Indonesia atas pemenuhan hak pendidikan di wilayah perbatasan. Selain itu juga dilakukan untuk memberikan jawaban terkait isu hukum yang penulis kaji terutama berkaitan dengan pemenuhan hak pendidikan di wilayah perbatasan yang sesuai dengan prinsip-prinsip negara hukum dan berdasartkan konstitusi Bangsa Indonesia.

Sebagai penelitian hukum normatif, maka pengumpulan data dalam penelitian ini dilakukan melalui studi dokumen. Oleh karena data yang dikumpulkan dalam penelitian ini 
bersumber dari data sekunder maka alat pengumpulan data yang digunakan adalah studi dokumen yaitu dengan mempelajari, menganalisis dan mengkaji bahan hukum primer dan sekunder yang berkaitan dengan objek yang diteliti. Analisis data adalah uraian mengenai caracara analisis yaitu bagaimana memanfaatkan data yang terkumpul untuk dipergunakan dalam memecahkan masalah penelitian. Data yang diperoleh dari hasil penelitian kepustakaan yang berupa bahan-bahan hukum primer, sekunder dan tersier digunakan untuk menguraikan konsepsi-konsepsi maupun teori.

Data dalam penelitian ini dianalisis secara kualitatif yang artinya analisis ini hendak mencari kebenaran berdasarkan nilai atau kualitas data yang diperoleh. Untuk melakukan analisis secara kualitatif ini melalui tahap-tahap sebagai berikut: (1) mengumpulkan data; (2) data yang diperoleh selanjutnya dikelompokkan sesuai dengan obyek atau variable dalam penelitian, (3) data yang telah dikelompokkan tadi kemudian diuraikan dan dijelaskan, (4) data yang telah dijelaskan selanjutnya dievaluasi dengan menggunakan ketentuan-ketentuan hukum yang berlaku untuk melihat kesesuaian atau sebaliknya, dan kemudian dibandingkan, dan (5) menetapkan kesimpulan dan ius constituendum.

\section{Hasil dan Pembahasan}

\section{Pendidikan Dalam Hak Asasi Manusia}

Penelitian Pendidikan adalah hak asasi manusia dan telah memperoleh status sebagai salah satu hak asasi yang bersifat fundamental (Deklarasi Universal Hak Asasi Manusia 1948 ).Hak atas pendidikan tersebut merupakan bagian dari hak ekonomi, sosial, dan budaya, yang pemenuhannya merupakan bagian dari kewajiban negara kepada rakyatnya (Charles ;2009). Pada prinsipnya, setiap orang mempunyai hak yang sama untuk mengikuti pendidikan dan menikmati hasil-hasilnya pada semua tingkatan pendidikan tanpa diskriminasi. Pemerintah harus meletakkan pendidikan sebagai hak dan menyebarluaskan pemahaman akan hal itu (diseminasi), memonitoring dan mengevaluasi atas pelaksanaannya (monitoring dan evaluasi), dan melaksanakan kebijakan-kebijakan berdasarkan dua langkah terdahulu tersebut secara nyata (adjudikasi) (Keppres Nomor 40 Tahun 2004 ).

Dilain sisi, Robert McCorquodale (2009) menguatkan asumsi yuridis bahwa hak atas pendidikan dalam sistem hukum internasional memiliki sifat dasar yang memaksa karena subyek-subyek hukum internasional, khususnya organisasi internasional secara konsisten menempatkan kewajiban pemenuhannya secara imperatif bagi anggotanya. Dasar argumentasinya adalah organisasi internasional memiliki kewajiban internasional terhadap perlindungan HAM, khususnya pemenuhan hak atas pendidikan berdasarkan 3 (tiga) argumen hukum, yaitu: (1). Organisasi internasional tidak boleh bertindak bertentangan dengan kewajiban hukum yang dimiliki oleh anggotanya terhadap kewajiban mereka pada instrumen perlindungan hukum HAM yang diterimanya, khususnya pemenuhan hak atas pendidikan; (2). Organisasi internasional terikat pada hukum kebiasaan internasional mengenai perlindungan HAM sama seperti pada negara dan individu dalam memenuhi hak atas pendidikan yang telah menjadi tujuan utama dari pendiriannya; dan (3). Kewajiban hukum perlindungan HAM tersebut telah berkembang ke organisasi internasional secara langsung. Sebagai contoh mutakhir mengenai status hak atas pendidikan dalam sistem hukum internasional, Deklarasi HAM ASEAN mengambil ketiga argumen hukum ini sebagai rasionalitas dan fakta hukum pembentukan norma dan mekanisme pembentukan hak atas pembangunan (Heppy Ratna ;2009).

Sejalan dengan kedua argumentasi hukum tersebut di atas, Komite Hak Ekonomi, Sosial dan Budaya menyatakan bahwa: "State Parties should ensure that their actions as members of international organizatioions take due account of their rights to education. Accordingly, State parties that are members of international financial institutions, notably the International Monetary Fund, the World Bank, and regional development banks, should take steps to ensure that the right to education is taken into account in their lending policies, credit agreements and 
other international measures". Mudahnya, organisasi internasional terikat terhadap kewajiban pemenuhan dan perlindungan hak atas pendidikan dalam menjalankan fungsinya (Coomans and Kaminga (eds);2001). Selain itu, yurisprudensi internasional juga menguatkan argumentasi tersebut di atas bahwa organisasi internasional memiliki kewajiban pemenuhan dan perlindungan HAM secara langsung berdasarkan aplikasi hukum kebiasaan internasional sebagai sebuah penghormatan atas Piagam PBB (Blokker and Schemers;2003).

Dalam perkembangan terkini, hak atas pendidikan merupakan salah satu hak asasi dasar yang memungkinkan setiap manusia bisa berperan aktif dalam pembangunan. Dalam Preamble of the Declaration on the Right to Development, asas-asas dasar yaitu partisipasi dan non diskriminasi menjadi dasar utama dalam pengembangan pendidikan seseorang berdasarkan kesamaan dalam hal Negara berperan dan wajib menyediakan pendidikan bagi semua orang, menjamin bahwa setiap orang memiliki akses terhadap pendidikan tanpa ada diskriminasi (Van Bueren;1998), serta berkewajiban menghilangkan hambatan-hambatan dalam akses memperoleh pendidikan baik dalam bidang legislatif dan dalam bidang lainnya. Transformasi efektif nilai-nilai HAM dibidang pendidikan harus didasarkan pada asas ketersediaan (availibility), kesempatan memperoleh (accessability), asas penerimaan (acceptability) dan asas penyesuaian (adaptability) berdasarkan kondisi negara, lingkungan sosial dan interaksi kultural senyatanya, sehingga aplikasi dari penerapan nilai-nilai tersebut dalam pendidikan justru menjadi hak asasi manusia yang fundamental yang eksistensinya tidak dapat dikurangi dalam keadaan apapun (non derogable right).

\section{Perlindungan Hukum Terhadap Warga Negara Untuk Memperoleh Hak Pendidikan di Wilayah Perbatasan Indonesia dan Malaysia Dalam Kerangka Hak Asasi Manusia}

Dalam konteks legal, pemenuhan hak atas pendidikan merupakan sesuatu yang justisiabel bagi setiap orang untuk menerima, memperoleh dan menikmati pendidikan. Di lain pihak, negara berkewajiban untuk memenuhinya. Kualitas dan kuantitas pendidikan wajib dipenuhi oleh pemerintah sebagai penyelenggara negara. Pemahaman dalam kerangka pemahaman kolektif bahwa pendidikan sebagai sebuah hak akan memposisikan pendidikan sebagai sebuah kebutuhan bersama yang akan menentukan masa depan bangsa dan Negara Indonesia.

Pendidikan selain merupakan bagian dari hak asasi, di sisi lain juga merupakan prasyarat bagi pelaksanaan, pemajuan dan perlindungan hak asasi manusia (Rodham;1973). Tingkat pendidikan dari orang perorang dan kolektif sebagai sebuah bangsa terbukti mempengaruhi pemajuan dan perlindungan hak asasi manusia. Demikian pula terhadap pemenuhan dan pemajuan hak ekonomi sosial dan budaya, pendidikan menjadi prasyarat utama bagi perealisasiannya (Todd Landman;2006). Toleransi, kesadaran dan pengembangan manusia seutuhnya menjadi tujuan penting pendidikan menurut Komite Hak Ekonomi, Sosial dan Budaya. Disamping itu, hak atas pendidikan di setiap tingkatan juga merupakan sarana yang paling penting untuk menciptakan suatu kebudayaan hak asasi yang universal (Van Bueren;1995).

Kewajiban tersebut berdasarkan pada aplikasi prinsip-prinsip dasar pemajuan dan perlindungan terhadap pilar-pilar dasar hak asasi manusia, yaitu kebebasan, kesamaan dan integritas. Ketiga dasar tersebut melahirkan semangat untuk menghormati (to respect) dan memenuhi (to fulfil) terhadap pemenuhan hak ekonomi, sosial dan budaya berdasarkan tiga kewajiban utama yaitu kewajiban pencapaian hasil (obligation of result), kewajiban melaksanakan kemauan dalam Konvensi (obligation of conduct) dan kewajiban pelaksanaan kewajiban-kewajiban tersebut secara transparan di dalam pengambilan keputusan (obligation transparent assessment of progress) terhadap indikator pemanfaatan dan pengunaan sumber daya maksimal yang tersedia (maximum available resources). Secara khusus, Indonesia terikat untuk melaksanakan kewajiban dalam pemenuhan hak atas pendidikan berdasarkan kewajiban 
untuk "undertakes to take steps, to the maximum of its available resources, with a view to achieving progressively the full realization of the rights recognized in the present Covenant.

Terbukanya akses pendidikan bagi semua warga negara merupakan conditio sine qua non dihargainya nilai kebebasan dan keadilan. Selama masih ada warga negarayang tidak dapat memperoleh akses pendidikan, meski di tingkat paling dasar, negara merupakan instansi yang paling bertanggung jawab atas ketidakadilan ini. Tanpa dijaminnya kebutuhan dasar ini, partisipasi warga dalam iklim demokrasi yang memungkinkan terjadinya pergerakan sosial ke atas kian jauh dari harapan. Yang miskin akan semakin miskin, yang tak berdaya akan semakin terperdaya. Dalam masyarakat demokratis, politik merupakan ekspresi kepercayaan publik, berupa amanah untuk menyejahterakan warganya, termasuk peningkatan kualitas pendidikan dan penguatan civil society (terbukanya peluang yang sama bagi tiap warga untuk aktif secara politis). Tanpa usaha ini, politik berubah menjadi wahana penguasaan sumber-sumber alam dan sosial bagi kepentingan segelintir orang. Karena itu, akses pendidikan bagi semua warga merupakan prioritas dasar sebab dengannya dijamin persamaan. Persamaan dalam mengenyam pendidikan memungkinkan tiap warga menghayati kebebasannya sehingga mereka mampu aktif berperan serta dalam kehidupan demokratif yang kian mengukuhkan martabat mereka sebagai manusia (Scot Colnan, 2008).

Berkaitan dengan hal tersebut di atas, penghapusan diskriminasi perlu kiranya dilakukan dengan memberi kesempatan yang seluas-luasnya kepada setiap warga negara untuk mengenyam pendidikan, sehingga sekolah murah, bahkan gratis, akan tercipta bagi segenap rakyatnya tanpa terkecuali. Oleh karenanya pemerintah dituntut untuk bisa berlaku adil dengan memberikan kesempatan yang sama bagi setiap warga negara untuk menempuh pendidikan (formal) dan mampu melindungi serta menjamin hak-hak warga negara terutama bagi mereka yang secara finansial tidak mampu supaya tetap bisa menempuh pendidikan yang layak (Emanuel Sujatmoko;2006).

Pemerataan pendidikan merupakan isu paling kritis karena berkait erat dengan isu sensitif, yakni keadilan dalam memperoleh akses pendidikan (Masenus Arus, 2001). Memperoleh pendidikan yang layak merupakan hak asasi setiap warga bangsa yang dijamin konstitusi (Putusan Mahkamah Konstitusi dalam Perkara Nomor 012/PUU-III/2005). Maka, pemerintah wajib memberi pelayanan pendidikan yang baik kepada seluruh masyarakat. Pendidikan menurut Pasal 1 angka 1 UU Nomor 20 Tahun 2003 tentang Sistem Pendidikan Nasional adalah usaha sadar dan terencana untuk mewujudkan suasana belajar dan proses pembelajaran agar peserta didik secara aktif mengembangkan potensi dirinya untuk memiliki kekuatan spiritual keagamaan, pengendalian diri, kepribadian, kecerdasan, akhlak mulia, serta keterampilan yang diperlukan dirinya, masyarakat, bangsa dan negara. Dengan demikian, pendidikan dapat diartikan baik sebagai proses maupun sebagai tahap khusus dalam proses tersebut.

Pada mulanya, pendidikan merupakan tanggung jawab masyarakat dan penduduk sebagai bentuk pemindahan keterampilan-keterampilan teknis yang diperlukan untuk menjalankan tugas dalam kehidupan sehari-hari, pemindahan nilai-nilai agama, filosofi, sosial dan budaya dari masyarakat dan penduduk tersebut kepada generasi yang lebih muda (Saksono, 2008). Baru setelah munculnya negara modern, pendidikan dianggap merupakan sebuah masalah publik yang pemenuhannya merupakan kewajiban negara. Pandangan bahwa pendidikan merupakan kewajiban negara disepakati baik oleh konsep liberal HAM maupun konsep sosialisme HAM. Dalam pandangan konsep liberal HAM, kewajiban negara untuk memenuhi hak pendidikan diletakkan berdampingan dengan kewajiban yang dimiliki oleh orang tua dalam memberikan pendidikan bagi anak-anak mereka (Fajar Susetyo ;2010). Kewajiban negara dalam hal ini adalah lebih pada aspek menjamin bahwa setiap anak menerima pendidikan yang cukup melalui pengaturan formal terhadap kurikulum sekolah-sekolah.

John Stuart Mill melukiskan hubungan antara kewajiban negara dan kewajiban orang tua dalam pendidikan tersebut sebagai berikut:"Jika pemerintah gigih menuntut hak pendidikan yang baik bagi setiap anak, maka pemerintah dapat mengusahakan sendiri suatu pendidikan 
yang baik. Pemerintah dapat menyerahkan kepada para orang tua kemungkinan untuk memperoleh pendidikan di mana dan sebagaimana mereka sukai dan merasa puas dengan membantu membayar uang sekolah anak-anak dari golongan yang lebih miskin dan membiayai seluruh biaya sekolah mereka" (Leo Zwaak, 2001). Sedangkan dalam pandangan sosialisme, pemenuhan hak atas pendidikan merupakan salah satu tugas utama negara. Pengaruh yang cukup besar dari ideologi sosialisme terhadap pemikiran founding fathers Indonesia menyebabkan pandangan inilah yang diterima dan dirumuskan sebagai salah satu tujuan negara Indonesia sebagaimana termuat dalam Pembukaan UUD 1945.

Tujuan pendidikan adalah untuk memungkinkan setiap manusia dapat mengembangkan martabat dan kepribadiannya secara bebas sehingga secara aktif dapat berpartisipasi dalam suatu masyarakat yang bebas dan mengupayakan hidup yang toleran dan menghormati HAM (Elsam, 2005). Deklarasi Universal Hak Asasi Manusia (Duham) juga mengakui bahwa tujuan dan sasaran pendidikan mempunyai kaitan dengan HAM. Dalam Pasal 26 ayat (2) Duham ditetapkan bahwa:"Pendidikan hendaknya diarahkan pada pengembangan kepribadian secara penuh dan untuk memperkuat penghormatan terhadap hak asasi manusia dan kebebasankebebasan dasarnya. Pendidikan tersebut harus memajukan pemahaman, toleransi, dan persahabatan di antara semua bangsa, kelompok-kelompok agama, dan ras, dan hendaknya melanjutkan kegiatan-kegiatan Perserikatan Bangsa-Bangsa untuk mempertahankan perdamaian" (Hermawan Bangun, 2006).

Sementara ICESCR dalam Pasal 13 ayat (1) menyebutkan bahwa pendidikan:“... harus diarahkan pada perkembangan kepribadian manusia seutuhnya dan kesadaran akan harga dirinya, dan memperkuat penghormatan atas hak-hak asasi dan kebebasan manusia yang mendasarbahwa pendidikan harus memungkinkan semua orang untuk berpartisipasi secara efektif dalam suatu masyarakat yang bebas, meningkatkan rasa pengertian, toleransi serta persahabatan antar semua bangsa dan semua kelompok, ras, etnis atau agama, dan lebih memajukan kegiatan-kegiatan Perserikatan Bangsa-Bangsa untuk memelihara perdamaian." Dalam Pasal 3 UU No. 20 Tahun 2003 tentang Sisdiknas, disebutkan bahwa tujuan pendidikan nasional adalah untuk berkembangnya potensi peserta didik agar menjadi manusia yang beriman dan bertakwa kepada Tuhan Yang Maha Esa, berakhlak mulia, sehat, berilmu, cakap, kreatif, mandiri, dan menjadi warga negara yang demokratis serta bertanggung jawab (Diah Harianti;2007). Kesemua tujuan tersebut hanya dapat dibentuk dan dikembangkan melalui pendidikan dasar dan menengah sebagai fondasi bagi pelaksanaan dan pencapaian tujuan pendidikan pada umumnya.

Pembagian HAM ke dalam 3 generasi yang pertama kali dicetuskan oleh Karel Vasak pada tahun 1979 memilah-milah HAM menjadi hak-hak sipil dan politik (generasi pertama), hak ekonomi, sosial dan budaya (generasi kedua), dan hak atas pembangunan atau hak solidaritas (generasi ketiga) (Bambang Indriyanto ;2004). Hak atas pendidikan, meskipun dalam beberapa aspek dapat dimasukkan dalam generasi pertama, namun kesepakatan untuk memasukkan hak atas pendidikan sebagai salah satu jenis hak dalam generasi kedua. Kesepakatan untuk memasukkan hak atas pendidikan dalam generasi kedua HAM jelas sekali jika kita melihat pengaturan mengenai hal tersebut yang dimuat dalam ICESCR.

Sebagai salah satu jenis hak generasi kedua HAM, hak atas pendidikan tidak terlepas dari ciri-ciri yang melekat pada hak ekonomi sosial dan budaya. Secara klasik, generasi kedua dikenali dengan ciri-ciri sebagai berikut, yaitu: (a). Mencapai atau meraihnya dilakukan secara bertahap; (b). Campur tangan atau keaktifan negara sangat dituntut dalam pelaksanaannya; (c). Pelanggaran terhadapnya tidak bisa diajukan ke pengadilan; (d). Ketergantungan pada sumber daya yang ada; dan (d). Bersifat ideologis.Meskipun kesahihan dari ciri-ciri klasik sulit untuk dipertahankan, namun secara umum pelaksanaan hak-hak generasi kedua HAM memang tidak terlepas dari hal tersebut. Dengan demikian jelas bahwa campur tangan negara.

Namun ciri-ciri di atas hanya berupa generalisasi saja. Kajian-kajian mutakhir menunjukkan bahwa ciri-ciri tersebut tidak selalu sahih. Hak ekonomi, sosial dan budaya tidak 
sepenuhnya merupakan hak-hak positif karena cukup banyak hak yang dikategorikan sebagai hak tersebut menghendaki negara tidak ikut campur dalam hal tersebut. Sebagai contoh misalnya kebebasan memilih sekolah, kebebasan melakukan riset, dan sebagainya (Tanamas, 1999). Selain itu, meskipun hak-hak generasi kedua HAM mengakui pencapaian secara bertahap dan realitas keterbatasan sumber daya pada satu sisi, namun pada sisi yang lain ia menghendaki adanya efek segera, dan sama dengan hak sipil dan politik, pelanggaran terhadap ini dapat diajukan ke pengadilan. Sebagai contoh dapat kita lihat gugatan class action yang dilakukan berkenaan dengan tidak dipenuhinya ketentuan anggaran pendidikan minimal 20\% dari APBN oleh pemerintah.

Kewajiban negara berkaitan dengan HAM adalah untuk melindungi, memajukan, memenuhi dan menghormati. Berkaitan dengan hak atas pendidikan kewajiban negara tersebut berkaitan dengan segala upaya agar hak tersebut dapat dinikmati oleh semua orang tanpa diskriminasi atau memerangi semua ketidakadilan yang ada dalam mengakses dan menikmati pendidikan. Kewajiban negara ini dapat diwujudkan melalui pembuatan peraturan-peraturan ataupun cara-cara lain untuk memajukan persamaan kesempatan dan perlakuan dalam pendidikan sebagaimana ditetapkan dalam Konvensi Melawan Diskriminasi dalam Pendidikan yang disepakati oleh Konferensi Umum UNESCO pada tanggal 14 Desember 1960 (Stephen Parker ; 1991).

Pasal 13 dan 14 ICESCR telah menetapkan kewajiban-kewajiban internasional yang mengikat setiap negara yang meratifikasi kovenan ini pada intinya adalah kewajiban untuk memberikan pendidikan pada setiap orang dan pemenuhan pendidikan dalam setiap jenjang dengan kemudahan pada obyek pendidikan seperti penyelenggaraan pendidikan dasar yang wajib dan cuma-cuma, pengembangan pendidikan lanjutan dan pelaksanaan komitmen melaksanakan pendidikan fundamental. Kegagalan negara dalam melaksanakan salah satu kewajiban tersebut di atas merupakan pelanggaran terhadap hak-hak tersebut. Selain terkena pelanggaran karena tidak menghormati hak tersebut, negara juga dapat dikatakan telah melakukan pelanggaran karena tidak melakukan perlindungan, di mana negara berkewajiban untuk mencegah pelanggaran hak atas pendidikan. Bahkan seringkali, negara bukan saja melakukan pembiaran terhadap tindakan-tindakan pelanggaran namun justru negara sendiri yang menjadi pelaku pelanggaran tersebut.

\section{Simpulan dan Saran}

Pendidikan merupakan tanggung jawab masyarakat dan penduduk sebagai bentuk pemindahan keterampilan-keterampilan teknis yang diperlukan untuk menjalankan tugas dalam kehidupan sehari-hari, pemindahan nilai-nilai agama, filosofi, sosial dan budaya dari masyarakat dan penduduk tersebut kepada generasi yang lebih muda. Baru setelah munculnya negara modern, pendidikan dianggap merupakan sebuah masalah publik yang pemenuhannya merupakan kewajiban negara. Kewajiban negara khususnya Indonesia untuk memenuhi hak pendidikan di wilayah perbatasan dengan Malaysia diletakkan berdampingan dengan kewajiban yang dimiliki oleh orang tua dalam memberikan pendidikan bagi anak-anak mereka. Kewajiban negara dalam hal ini adalah lebih pada aspek menjamin bahwa setiap anak menerima pendidikan yang cukup melalui pengaturan formal terhadap kurikulum sekolahsekolah. Hal ini yang harus diperhatikan oleh pemerintah Indonesia untuk terus memberikan perlindungan hukum berkaitan dengan hal pendidikan warga negara yang ada di wilayah perbatasan dengan Malaysia sehingga tidak bertentangan dengan hak asasi manusia.

\section{Daftar Pustaka}

Baehr, Peter, Pieter Van Dijk, Adnan B. Nasution, Leo Zwaak, (2001), Instrumen Internasional Pokok Hak-hak Asasi Manusia, Yayasan Obor Indonesia, Jakarta. 
Bambang Indriyanto, (2004), HAM Dalam Konteks Kurikulum Nasional Dan Lokal, Jurnal Hukum dan HAM Bidang Pendidikan, Vol. 2 No. 3 Desember 2004.

Beitz, Charles, (2009), The Idea of Human Rights, Oxford University Press, 2009.

Biro Hukum dan Organisasi Setjen Kemdikbud, (2012), "Monitoring dan Evaluasi Pemenuhan Hak Atas Pendidikan di Indonesia Tahun 2011", Biro Hukum dan Organisasi Setjen Kemdikbud.

Blokker and Schemers, (2003), International Institutional Law, Fourth Edition, Leiden.

Bonanza Perwira Taihitu, (2003), "Penaatan Indonesia Pada Standar-Standar Hak Asasi Manusia Internasional", Thesis Fisipol UI, Universitas Indonesia.

Budi Hermawan Bangun, (2006), Pengantar Hukum dan HAM, Fakultas Hukum Untan, Pontianak.

Colin Wringe, (2006), Moral Education: Beyond the Teaching Rights and Wrong, Springer.

Committe on Economic, Social and Cultural Rights, General Comments 15: The Rights To Water", UN Doc. E/C.12/2002/II, 2002, para. 36.

Committee on Economic, Social and Cultural Rights General Comment 13, The Right to Education (Art. 13), 08/12/99, E/C.12/1999/10, CESCR, 8 December 1999, para 1; pernyataan ini didukung oleh the World Bank in Crying Out for Change, World Bank in three volumes (2002).

Coomans and Kaminga (eds), (2001), Extraterritorial Application of Human Rights Treaties, Antwerp, 2004, hlm. 214 dan Reinisch, "Securing the Accountability of International Organizations", 7 Global Governance.

Deklarasi Universal Hak Asasi Manusia 1948

Diah Harianti, (2007), "Presentasi HAM dan KTSP, Pelatihan HAM Bagi Guru Se Propinsi Sumatera Barat, Padang, Juni 2007.

Elsam, (2005), "Ekspektasi yang Sirna", Laporan Penegakan HAM 2005, Lembaga Studi dan Advokasi Masyarakat (Elsam), Jakarta.

Emanuel Sujatmoko, et. al, Hak Warga Negara untuk Memperoleh Pendidikan Dasar, dalam Jurnal Hukum dan HAM Bidang Pendidikan Vol. 4 No. 1 Juni 2006, Biro Hukum dan Organisasi Departemen Pendidikan Nasional, Jakarta.

Gatut Saksono, (2008), Pendidikan yang Memerdekakan Siswa, Rumah Belaajar Yabinkas.

General Assembly Resolution 41/128 of 4 December 1986, see <http://www.unhchr.ch/html.menu3/b/74.htm>, United Nations, Human Rights: A Compilation of International Instruments (1993, Vol. I second Part).

Geraldine Van Bueren, (1995), The International law on the Rights of Child, the World Declaration on Education for All.

Heppy Ratna, AICHR dan Penguatan Perlindungan HAM di ASEAN, http://news.antara.co.id/berita/1256362459/aichr-dan-penguatan-perlindungan-hamdi-asean, 2009; dan Human Rights Committee, General Comment 3, Article 2, para 1, Implementation at the national level (Thirteenth session, 1981), Compilation of General Comments and General Recommendations Adopted by Human Rights Treaty Bodies, UN Doc. HRI/GEN/1/Rev.1 at 14 (1994), University of Minnesota Human Rights Library, http://www1.umn.edu/humanrts-/gencomm/hrcom13.htm.

Hillary Rodham, (1973), "Children Under the Law",43 Harvard Educational Review.

Ifdal Kasim dan Johanes Masenus Arus, (2001), Hak Ekonomi, Sosial dan Budaya”, Esai-Esai Pilihan, Elsam.

Keppres Nomor 40 Tahun 2004 Tentang Rencana Nasional HAM RI dan Peraturan Presiden Nomor 23 tahun 2011 Tentang Aksi Nasional HAM tahun 2010-2015.

Klaus Dieter Beiter. (2005), The Protection of the Right to Education by International Law, Martinus Nijhoff Publisher.

Kovenan Hak Ekonomi Sosial dan Budaya 1966. 
Kovenan Internasional tentang Hak-Hak Ekonomi, Sosial dan Budaya yang termuat dalam Lembaran Negara Republik Indonesia Tahun 2005 Nomor 118, Tambahan Lembaran Negara Republik Indonesia Nomor 4557.

M Santos Pais, “A Human Rights Conceptual Framework for Children's Rights” dalam UNICEF Innovative Essay No.9.

M. Freeman, (1992), “The Limits of Children's Rights, dalam The Ideologies of Children's Rights.

Manfred Nowak, "The Right to Education" dalam Asbjorn Eide (et.all),1995, Economic, Social and Cultural Rights, A Textbook.

Muhammad Joni Zulchaina Z. Tanamas, (1999), Aspek Hukum Perlindungan Anak Dalam Perspektif Konvensi Hak Anak, PT Citra Aditya Bakti, Bandung.

Phnom Penh Statement on the Adoption of the ASEAN Human Rights Declaration (AHRD), 18 November 2012.

Putusan Mahkamah Konstitusi dalam Perkara Nomor 012/PUU-III/2005 Mengenai Pengujian Undang-Undang Nomor 36 Tahun 2004 Tentang Anggaran Pendapatan Belanja Negara.

Robert McCorquodale, (2009), International Organizations and International Human Rights Law: One Giant Leap for Humankind, in Kaiyan Homi Kaikobad and Michael Bohlander, International and Power Perspective on Legal Order and Justice, Martinus Nijhoff Publishers.

Scot Colnan, (2008), The Effectiveness of Domestic Human Rights NGO's, Martinus Nijhoff Publisher, Leiden Boston.

Stephen Parker, (1991), "How Can Rights-Talk Help Children: An Academic Perspective", dalam Phillip Alston and H. Brennen, The UN Children's Convention and Australia.

Todd Landman, (2006), Studying Human Rights, Oxford University Press.

Undang-Undang Nomor 20 tahun 2003 tentang Sistem Pendidikan Nasional.

Yosep Adi Prasetyo, (2012), "Hak Ekosob dan Kewajiban Negara", Pemerkuatan Hak Asasi Manusia Untuk Hakim Seluruh Indonesia, Holiday Resort Lombok, 28-31 Mei 2012.

Yuli Fajar Susetyo, (2010), "Pendidikan Humanis", Modul Pembelajaran Penataran Hak Asasi Manusia Bidang Pendidikan Se-Provinsi kalimantan Barat, Biro Hukum Hukum dan Organisasi Setjen Kemdikbud-UGM. 